\title{
THE ORIGIN OF MATTHEW'S GOSPEL.
}

\section{A Suggestion.}

\section{S. M. Provence, D.D., Texas.}

The literature of the times immediately after the Apostles is scant, scrappy, and unreliable as to dates. We have almost nothing dependable except a few quotations before the close of the first century A. D. From about 98 or 100 onward the volume of literature increases, but much of that which is assigned to the first half of the second century is lacking in clear evidence both as to date and authorship. No doubt most of this has suffered at the hands of eritics, who have sought in its tangled maze support for every vagary of interpretation. It would seem now, however, to be established beyond reasonable question that the earliest non-canonical writers of whom we have any knowledge were familiar with the four Gospels. Quotations found in their writings which are still extant, and references to others which have been lost, show that at the earliest reliable dates of these writings, "the texts of our Gospels ran essentially as we now have them, but that intentional changes were not wanting about the middle of the second century" (A. Harnack, "Tatian," Enc. Brit., 9th ed.). It is worthy of notice, in passing, that one of these additions appears to be Matt. $16: 18,19$.

There is no need to reproduce here the details which are more or less known to every student. Any good introduction will give the facts ; for example, Ezra Abbott's "The Fourth Gospel," or Hovey's General Introduction to "An American Commentary," prefixed to Matthew. The point to be noted here is that the literary phenomena set forth by writers on Introduction afford no sufficient ground for supposing that the Gospels "as we now have them," which are "essentially" as they were when the earliest writers began to study them, are in any true sense a literary growth. On the contrary, all the evidence 
points to the composition of these Gospels, each by the man whose name it bears. The circumstances under which they were used in the defence of Christianity, the abuses they suffered at the hands of hostile critics, the fact that there were no conveniences for verifying quotations (which were therefore apparently wholly from memory), sufficiently account for the way these Gospels were quoted.

Since the modern attacks upon the credibility and the authenticity of the Gospels began, ingenuity has taxed itself to the last extremity to account for them. For example, the "triple tradition" theory, founded on the material common to the first three Gospels, with the curious argumentation which is employed in its support, is indicative of a determination little short of desperation to destroy the authenticity of these Gospels. Crities who have taken the labor of writing out these common words and phrases seem to have overlooked their hopelessness in the task of showing that their so-called "triple tradition" is not itself a result of an anterior process of selection-a residuum of the teaching of an indefinite number of men, each differing from the others in his conception of the life and purpose of Jesus, and in his own immediate purpose. It is inherently more difficult to account for the "triple tradition" than it is to account for either of our Gospels. Let any unbiased student look at this patch-work thing and ask himself who could have made it? And the sheer desperation of the whole theory is further seen in the attempt to show that Kata Mathaion, Kata Markon, and so on, do not imply authorship (Gospels, in Ene. Brit. 9th ed.); so that it is merely accidental, or due to some unexplained circumstance, that these Gospels bear the name they do.

The fact that the Gospels, "essentially as we now have them," antedate all discussion of them and all reference to them, would seem to have been sufficient to protect them from mistreatment of this kind, even at the hands of their enemies. 
The question of the interdependence of the Gospels is of a different nature, since it involves that of priority. Down to 1785, A. D., the judgment of Augustine, that "Mark was the abbreviator of Matthew" was accepted with practical unanimity. The suggestion of a common written source was first offered by Lessing. Naturally enough, when mere guess-work was begun it did not stop with one guess. In 1818, Lessing's guess was followed by that of an "oral tradition." Westeott gave this a temporary prominence. The gist of this tradition is that there were in common use some time in the latter half of the first century a number of unwritten stories, incidents, sayings, sermons and the like, which finally got themselves committed to writing. Westcott undertook the labor of gathering out the coincidences in the first three Gospels. His celebrated table of differences runs thus: If the contents of each of these Gospels be represented by 100, Mark will have seven peculiarities and ninetythree co-incidences; Matthew will have forty-two peculiarities and fifty-eight coincidences; Luke will have fiftynine peculiarities and forty-one coincidences.

Now, instead of concluding that practically ninetythree per cent of iMark has been borrowed by the others, why may it not be just the other way around? Certainly, no one can prove that it is not, and "internal evidence", in a matter of this kind is entirely too subjective to be reliable. Besides, there are some indisputable facts which seem clearly to point to the priority of Matthew's Gospel: 1. Matthew, as has often been stated, was accustomed to keeping accounts. His practice of writing would naturally make him the fittest of all the Twelve for such an undertaking. 2. His Gospel begins with a statement of the thesis which he intends to prove: "An Account of Jesus, Messiah, a Descendant of David, a Descendant of Abraham." The descent he shows from the genealogical tables. The Messiahship is the theme about which he marshals his facts. 3. The appeal of Jesus was first to His own people. The key-note of Matthew's writing is 
therefore "Believe!" For a Jew to believe that Jesus was the promised Messiah meant instant surrender to Him as Lord. So it does to this day! Matthew is not therefore concerned with chronological order. He masses his facts for the sake of cumulative force. His climax is the Messianic claim of universal power based upon and proved by the resurrection. This Gospel is therefore a continuance of the appeal of John the Baptist and of Jesus. 4. Jesus called Matthew from his custom-house and his book-keeping. What was His purpose? That He had a purpose no one can deny who believes in His Messiahship. It would seem indisputable that His purpose was that Matthew should use his skill in preparing a historical argument for the Messiahship.

The supposition that Matthew began at once accounts for two characteristic features of his Gospel-its vividness and its quotations from the Old Testament. It explains, too, how Matthew came into possession of facts which in the nature of things could have been known only to Jesus. It has been questioned whether any New Testament writer ever quotes directly from the Hebrew Old Testament. They quote almost wholly (if not altogether) from the Greek version. This was the only Bible then in common use among the people. If there be any quotations from the Hebrew, they are in Matthew's Gospel. Sometimes Matthew quotes the Greek precisely; sometimes he corrects it to make it conform more nearly to the meaning of the Hebrew original; sometimes he changes it so that it appears to be an exact representation of the Hebrew. These quotations are so apposite and so suggestive that no one but a master in historical theology could have made them. And the changes in the Greek show an acquaintance with both the Greek and the Hebrew which may well be judged impossible to a nonprofessional man. "Unlearned and ignorant" the Twelve certainly were not. They were "non-professional and private" citizens (Acts 4:13); but it would be an extraordinary thing to find a tax-collector so completely 
master of the Old Testament in both Hebrew and Greek as to quote freely and fittingly, and to correct the Greek from the Hebrew. Besides, there were no referencebooks. Matthew had no such contrivance as a concordance. If we suppose that Jesus had devoted much of His private life to the study of the Old Testament in Greek and Hebrew, or if we suppose that He already knew both, Matthew's quotations, with all their striking masterfulness, are accounted for by the further supposition that he wrote at least the most of his Gospel under our Lord's supervision.

On the other hand, taking the author of our second Gospel to be the Mark referred to in the Acts, he must have been a very young man when he went with Paul and Barnabas to Asia Minor. The earliest known statement about his Gospel is that which is quoted by Eusebius from Papias (whose work is lost), namely, that "Mark, having become the interpreter of Peter, wrote down accurately everything he remembered, without, however, recording in order what was said or done by Christ. For neither did he hear the Lord, nor did he follow Him; but afterward, as I said (he heard and followed) Peter, who adapted his instructions to the needs (of his hearers), but had no design of giving a connected account of the Lord's oracles (or discourses). So then Mark made no mistake while he thus wrote down some things as he remembered them; for he made it his care not to omit anything that he heard, or to set down any false statement therein" (Am. Com., Matthew, p. xvi). On the supposition that this was the first Gospel, one must account for the tradition of a Hebrew Gospel by Matthew (also quoted by Eusebius from Papias), for the implied neglect of the Jews, inasmuch as Mark's Gospel was clearly for non-Jews, and for the failure of the fittest man of the whole Twelve to take up his task until after Mark's Gospel had obtained a wide circulation.

As to the tradition of a Hebrew Gospel by Matthew, it may well have been known at the time that he wrote 
largely in his own vernacular Aramaic. This was also our Lord's native tongue. When He spoke in that tongue, Matthew would naturally take notes in the same tongue. When the Lord spoke in Greek, Matthew would easily follow Him in that tongue. The bulk of this first draft would be in Aramaic, still called the Hebrew in our Lord's time. When Matthew put his Gospel into its final shape, its hebraisms would almost inevitably appear in his Greek. And this is just what we find. There is no way of finding out how long Matthew took in this final work, nor what interval passed before he took it up after the resurrection of our Lord. But on the suggestion here offered, even if Mark got his material chiefly from Peter, there is no inherent impossibility in the supposition that Peter knew Matthew's Gospel. And if he went eastward into Syria and took Mark with him, as he seems to have done (there appears to be no historical evidence that he was ever in Rome), Mark's omissions of reference to Jewish history and the Messiahship, and his explanations of Jewish customs, find satisfactory explanation. He was writing for the people among whom he and Peter were preaching.

Other considerations appear to support the suggestion here offered. If one will compare the hesitant, argumentative, and uncertain tone of the literature still extant from the latter part of the first century to the end of the second, with the poise and calmness and certitude of the Gospel writers, he must conclude that these had something that later writers did not have. Besides, it would seem incredible that our Lord would have left the facts of His life and death and resurrection, and the teaching dependent upon them, to the crude and uncertain literary methods of His time and country. The evolution of our Gospels, with their tone of authority and verity, from the membra disjecta of the scattered and persecuted disciples, would be a far more incredible literary miracle than anything set down in these books. 